\title{
The influence of atmospheric circulation on the air pollution concentration and temperature inversion in Sosnowiec. Case study
}

\author{
Artur Widawski \\ Department of Climatology, Faculty of Earth Sciences, University of Silesia, Będzińska Str. 60, 41-200 Sosnowiec, Poland \\ E-mail address: artur.widawski@op.pl
}

\begin{abstract}
Sosnowiec is located in the Katowice Region, which is the most urbanized and industrialized region in Poland. Urban areas of such character favor enhancement of pollution concentration in the atmosphere and the consequent emergence of smog. Local meteorological and circulation conditions significantly influence not only on the air pollution level but also change air temperature considerably in their centers and immediate vicinities. The synoptic situation also plays the major role in dispersal and concentration of air pollutants and changes in temperature profile. One of the most important are the nearground $(100 \mathrm{~m})$ inversions of temperature revealed their highest values on clear winter days and sometimes stay still for the whole day and night. Air temperature inversions in Sosnowiec occur mainly during anticyclone stagnation (Ca-anticyclone centre and Ka-anticyclonic ridge) and in anticyclones with air advection from the south and southwest (Sa and SWa) which cause significantly increase of air pollution values. The detailed evaluation of the influence of circulation types on the appearance of a particular concentration of pollutants carried out in this work has confirmed the predominant influence of individual circulation types on the development of air pollution levels at the Katowice region. This paper presents research case study results of the thermal structure of the near-ground atmospheric layer $(100 \mathrm{~m})$ and air pollution parameters (PM10, S02, NO, NO2) changes in selected days of 2005 year according to regional synoptic circulation types. The changes in urban environment must be taken into account in analyses of multiyear trends of air temperature and air conditions on the regional and global scales.
\end{abstract}

KEY WORDS: urban climate, macrocirculation types, PM 10, nitric oxide, nitrogen dioxide, sulphur dioxide, Katowice Region

\section{Introduction}

The Katowice region is the best illustration of an area that underwent complete anthropopression in Poland (Fig. 1). The wasteful economy of the $70 \mathrm{~s}$, characterized by a dynamic development in industry and urbanization, was the most strongly reflected in the level of pollutants emitted to the atmosphere. Nowadays, when the emission is reduced to a remarkable extent, it is important to examine the influence of atmospheric circulation on the sanitary condition of air. The issue discussed in this work is an example of the so-called synoptic meteorology and climatology, which evaluate the relation between environmental elements and circulation conditions.

Katowice Region consist of urbanized and industrial surfaces, therefore the regional climate differs considerably from the climate of non- urban areas. Modification and transformation of the cities climate by people is the most visible in diversification of local climate (PASZYŃSKI, 1997; WILMERS, 1997; GIRIDHARAN ET AL., 2005). Distortion of the active surface leads to appearance of local climatic and microclimatic structures in urbanized areas that are more complicated than their counterparts in the countryside (Oke 1999).There are different studies of the region, which confirmed the occurrence of the characteristic phenomena like: change of heat balance of active surface (WIATRAK, 1989; CAPUTA ET AL., 2003), urban heat island (OŚRÓDKA, 1991; KŁYSIK \& FORTUNIAK, 1999; SZYMANOWSKI, 2005), thermal inversion (BIL, 2000, 2009), smog (OŚRÓDKA ET AL., 1999), acid rain (LEŚNIOK, 1996; HŁAWICZKA ET AL., 2003), and changes in precipitation patterns (TWARDOSZ \& NIEDŹWIEDŹ, 2001). 


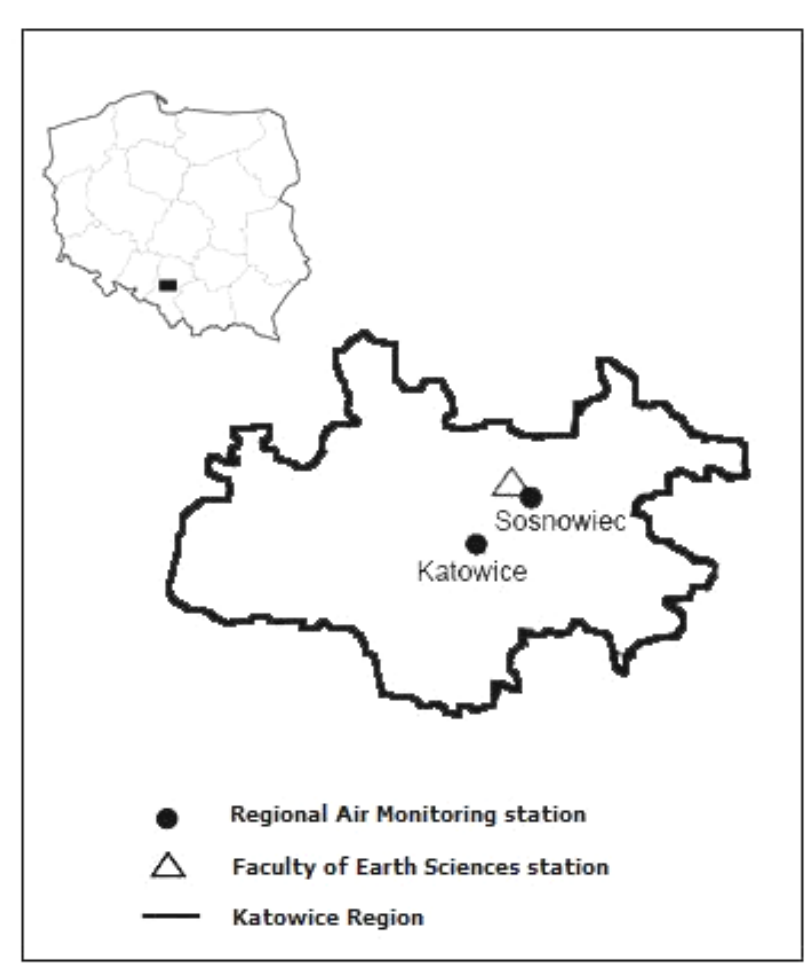

Fig.1. Localisation of regional air monitoring station in Katowice and meteorological station in Sosnowiec

Atmospheric circulation plays a major role in urban climate (HAEGER-EUGENSSON \& HOLMER, 1999), especially regarding the diffusion of pollution (NIEDŹWIEDź, 2005). The occurrence of specific pressure systems and air masses increases or decreases the influence of the anthropogenic factor, the intensity of the urban heat island and the level of atmospheric pollution. The dispersal and concentration of air pollutants researches, which were done in Kraków (NIEDŹwIEDŹ \& OLECKI, 1994) and Upper Silesia (NIEDźWIEDŹ \& USTRNUL, 1989; LEŚNIOK \& CAPUTA, 2009; LEŚNIOK ET. AL., 2010; LEŚNIOK, 2011; BIELEC-BĄKOWSKA ET. AL., 2011) makes it clear that the conditions favorable to the concentration of pollution (in winter in particular) emerge at the centre of a high or in situation of high pressure with an influx of air from the south-west (SWa). In those synoptic situation, a strong inversion arrives, preventing pollutants from escaping to higher layers of the atmosphere (NiEDźWIEDŹ, 2005).

Air contamination with particulate matter causes a serious problem in large cities and urban-industrial agglomerations both in Poland and its neighbors. The study integrated measured results of selected air pollution indices were made for different towns i.e. Sosnowiec (CEMBRZYŃSKA ET.AL., 2012; BIELEC-BĄKOWSKA ET. AL., 2011), Zabrze (RogULA-KoZŁOWSKA, 2013). The comparison of daily, seasonal and annual concentration of particulate matter in neighbors regions of Upper Silesia were investigated by KNozova $(2011,2012)$ in Brno, South Moravia and BIELEC-BĄKOWSKA ET. AL. (2011) in Cracow region.

The paper presents the results of the research on the thermal structure of the $100 \mathrm{~m}$ thick bottom layer of the atmosphere during strong thermal inversion and enhancement of pollution concentration during this episode in Sosnowiec. The most important correlation between air pollution counts, thermal inversion and synoptic situation are presented.

\section{Data and methods}

Meteorological data come from two automatic weather stations of Faculty of Earth Sciences, University of Silesia, in Sosnowiec (geographical coordinates: $19^{\circ} 08 \mathrm{E}, 50^{\circ} 17 \mathrm{~N}$ ). The first station is located on altitude $263 \mathrm{~m}$ a.s.l. above a grassy surface, which represents the typical conditions of a suburban area, The terrain is fiat with a low density housing development. The 20-storey building of the Faculty of Earth Sciences is located $80 \mathrm{~m}$ from the measurement area in the northeast direction. The surroundings of the station included green areas (Iawns and gardens), a power station located a few $100 \mathrm{~m}$ to the northeast and sparsely distributed apartment blocks, located a few $100 \mathrm{~m}$ to the south (Fig. 2). The station is equipped with a Vaisala thermohygrometer $(2 \mathrm{~m})$, a temperature soil probe (depth of $1 \mathrm{~m}$ ), an anemometer, a wind direction sensor (AlOOR $10 \mathrm{~m}$ ), and a Kipp and Zonen netradiometer CNRl (1.5 m).

The second station is located on altitude $263 \mathrm{~m}$ a.s.l. on the roof of the building at the height of $100 \mathrm{~m}$ above the ground and $7 \mathrm{~m}$ above the roof level (Fig. 2). The station was equipped with a Vaisala thermohygrometer, an anemometer, a wind direction sensor, a Kipp and Zonen sunshine sensor $\mathrm{CSDl}$, and a pyranometer. The data were registered with a Campbell logger CRIOx. The impact of the building on the readings from the sensor located above the building was insignificant in comparison with the measured inversion. The mean difference between the temperature measured by the sensor situated above the roof $(1,5 \mathrm{~m})$ and the sensor located at the highest location $(7 \mathrm{~m})$ equals +/- 0,4 K (BIL ET AL., 2003). It has been assumed that temperature bias at $100 \mathrm{~m}$ caused by the building should be of the same order of magnitude (see Figure 2). 


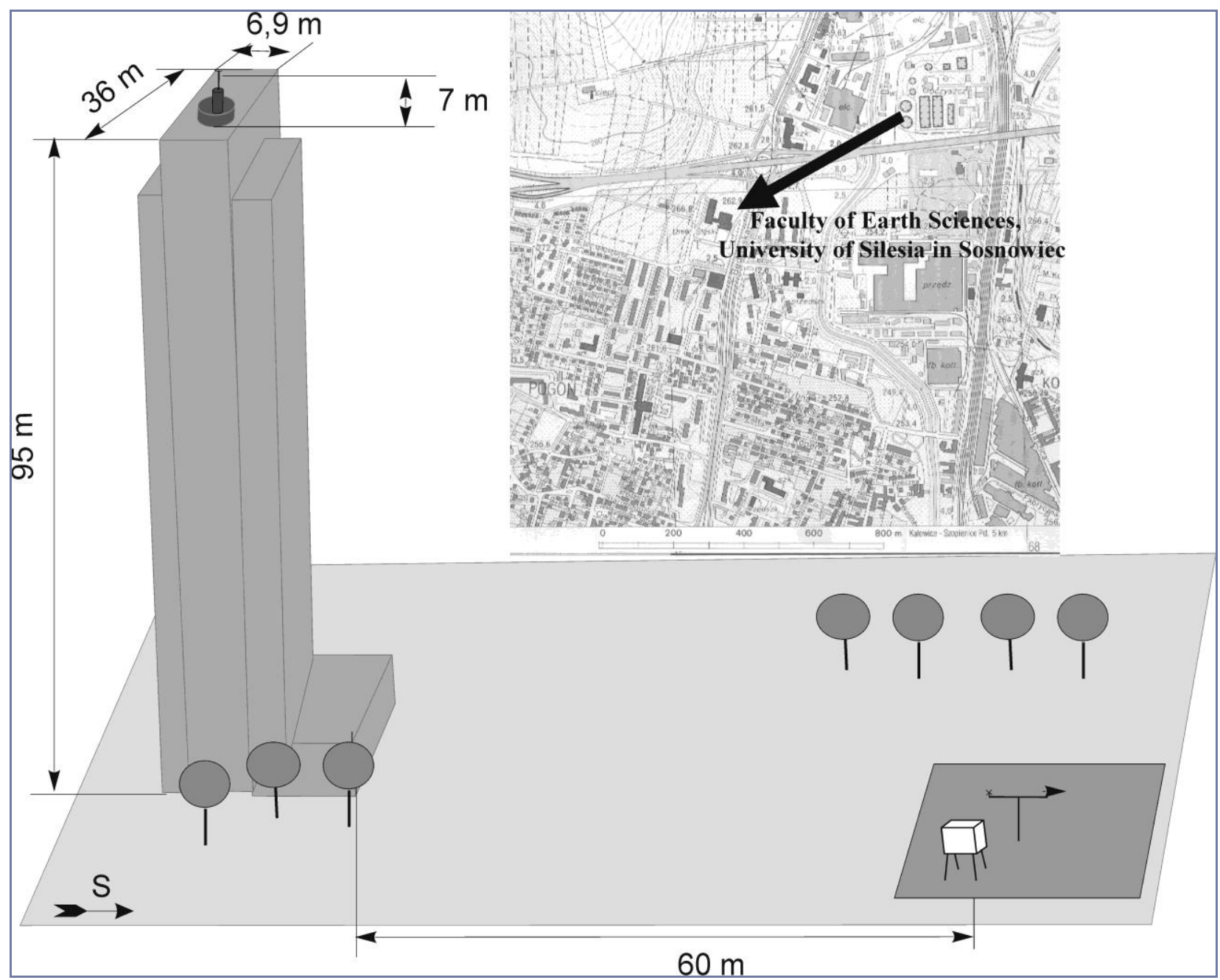

Fig. 2. Localisation of the Faculty of Earth Sciences meteorological stations in Sosnowiec. See text for explanations

For air pollution measurement the following pollutants were used: particulate matter (PM10) with a fraction size of up to $10 \mu \mathrm{m}$, sulphur dioxide $\left(\mathrm{SO}_{2}\right)$, nitric oxide (NO), nitrogen dioxide $\left(\mathrm{NO}_{2}\right)$. These data were collected from Katowice Raciborska street stations on the regional air monitoring network. This is the best environmental monitoring station and has the most complete and homogenous observation material in the whole Katowice region (BIULETYN..., 1999).

Additionally data of three upper air sounding station, which are the nearest to Sosnowiec were used for analyzing the vertical profile of thermal inversion depth. Sounding data came from University of Wyoming Weather Web, which provides free soundings data for all World (WYOMING, 2015).

\section{Synoptic situation and circulation types}

During 04-11 February 2005 Poland was under high pressure system from over Russia, which was the part of the Siberian high pressure (Fig. 3a).
In next few days it merged with the Azores high pressure creating over Europe an elongate area of high pressure, which was above $1045 \mathrm{hPa}$ in the centre (Fig. 3b, c). This area moved a little bit south in next few days. At night the temperature dropped below $-20.0^{\circ} \mathrm{C}$ (Suwałki, Nowy Sącz) and on the ground (5 centimeters) was - 28.0 to $26.0^{\circ} \mathrm{C}$ (Białystok, Suwałki, Nowy Sącz).

Starting from 10 February the pressure dropped quickly. The low-pressure system with $975 \mathrm{hPa}$ pressure in the centre, which formed at the Norwegian Sea started moving south and east south (Fig. 3d). Germany, northern, western and central Poland, the Baltic and Scandinavia was the area of increased wind speed. In Sosnowiec values of $16 \mathrm{~m} / \mathrm{s}$ (maximum wind speed) were recorded. Approaching the cold atmospheric front was accompanied by a pressure drop in Pomerania, Warmia and Mazury to $9 \mathrm{hPa} / 3 \mathrm{~h}$. On average pressure drop before the approach of the lowlands up to $3 \mathrm{hPa} / 3 \mathrm{~h}$. 


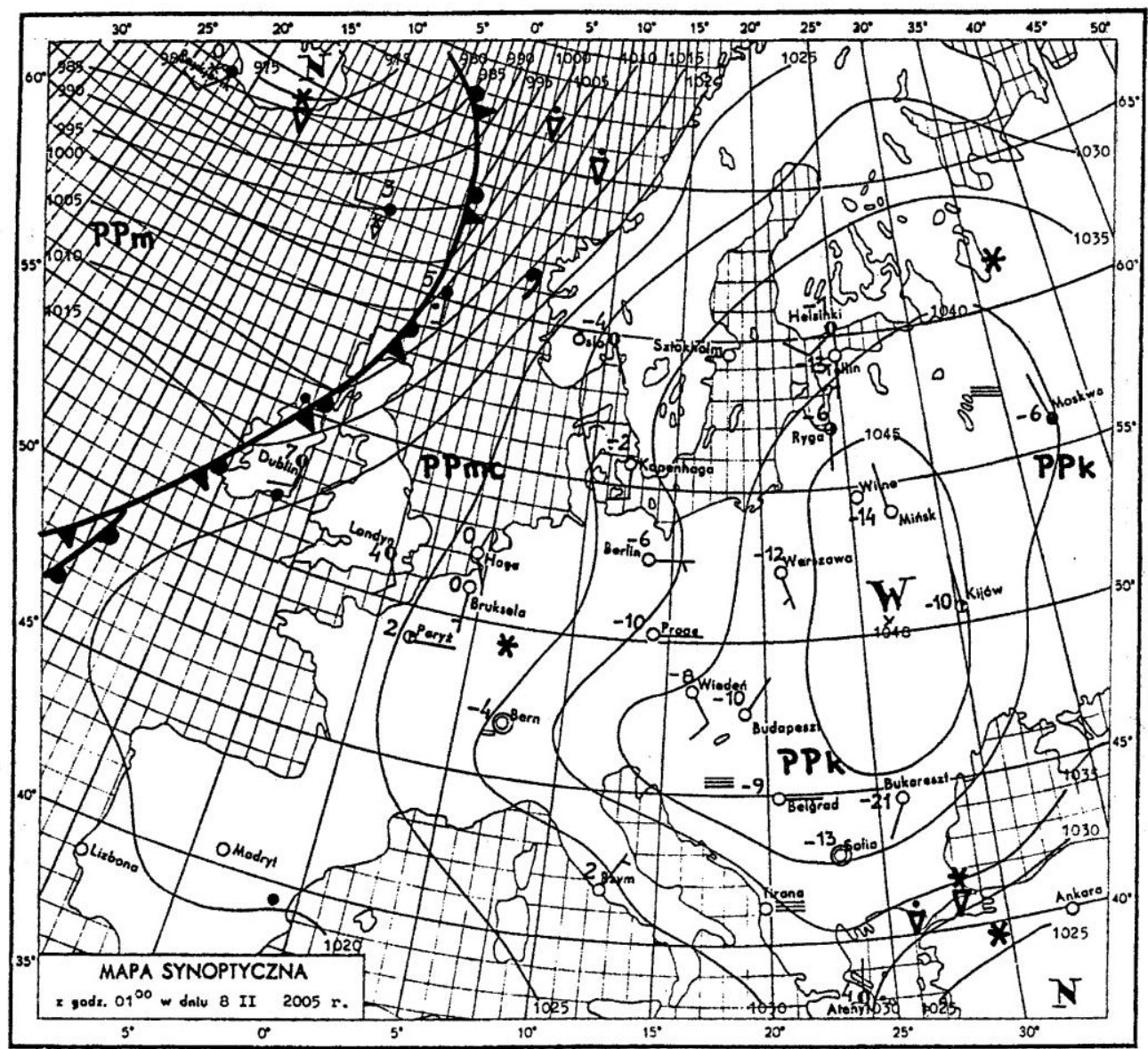

$3 a$

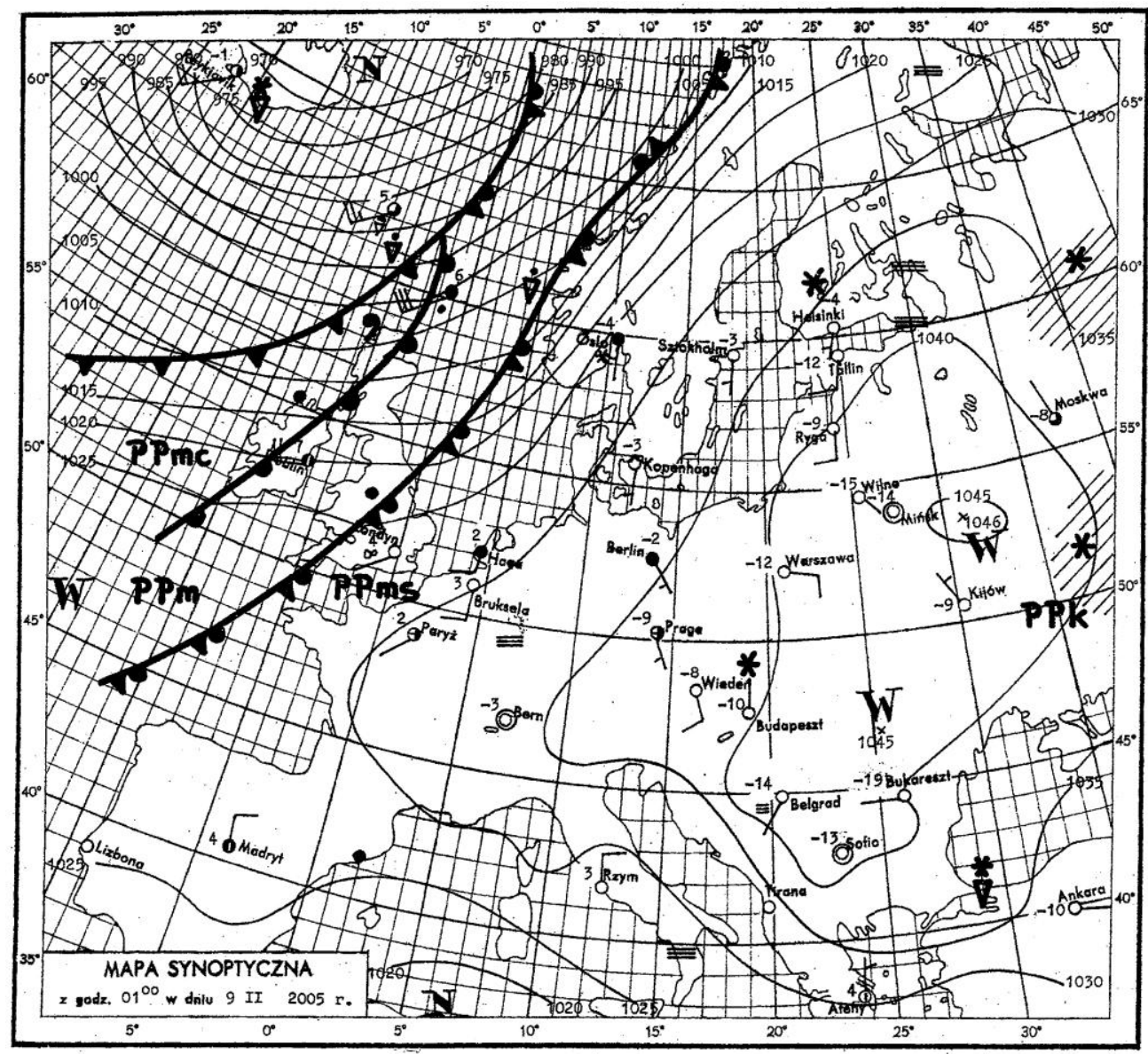

$3 b$ 


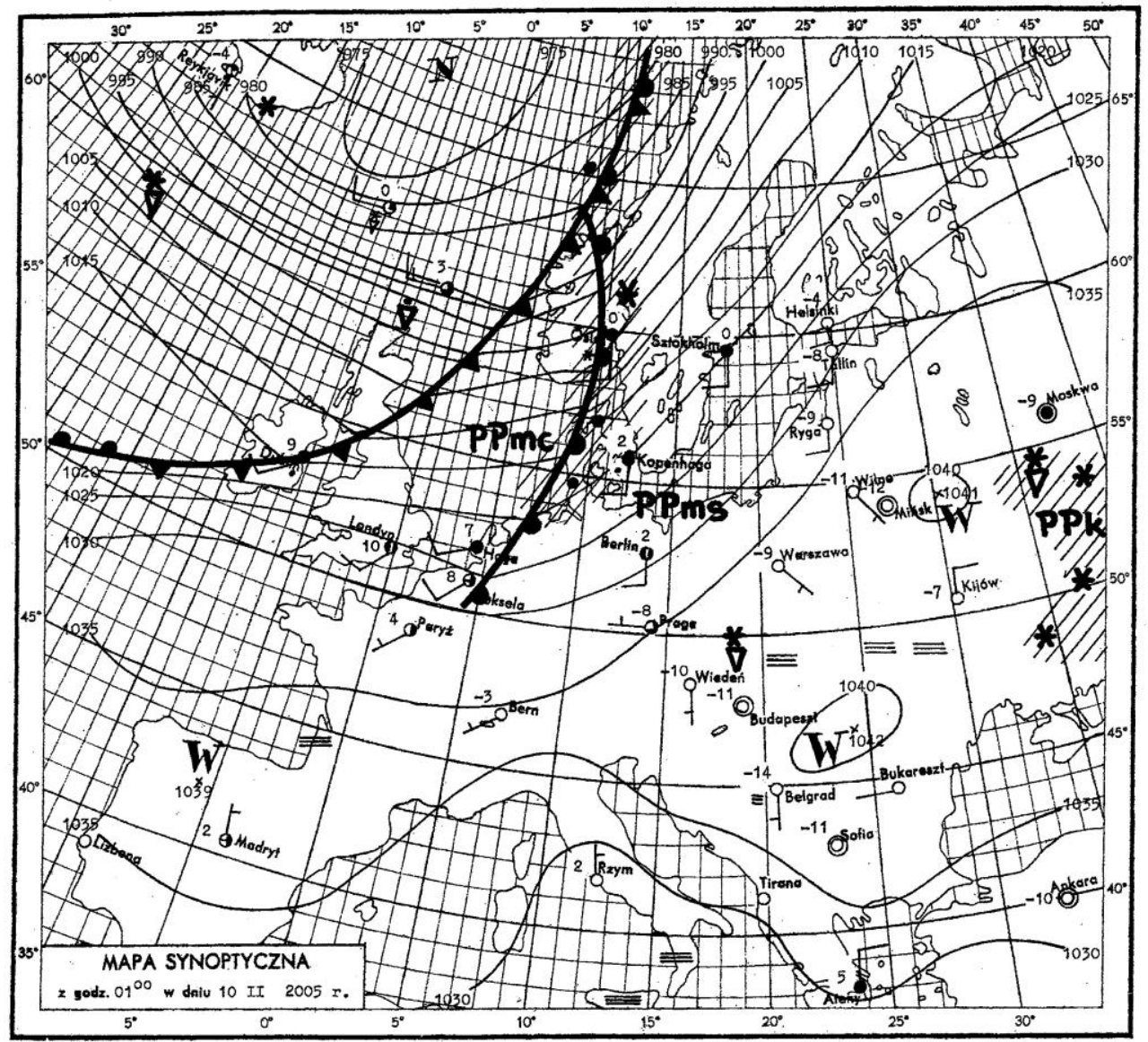

3c

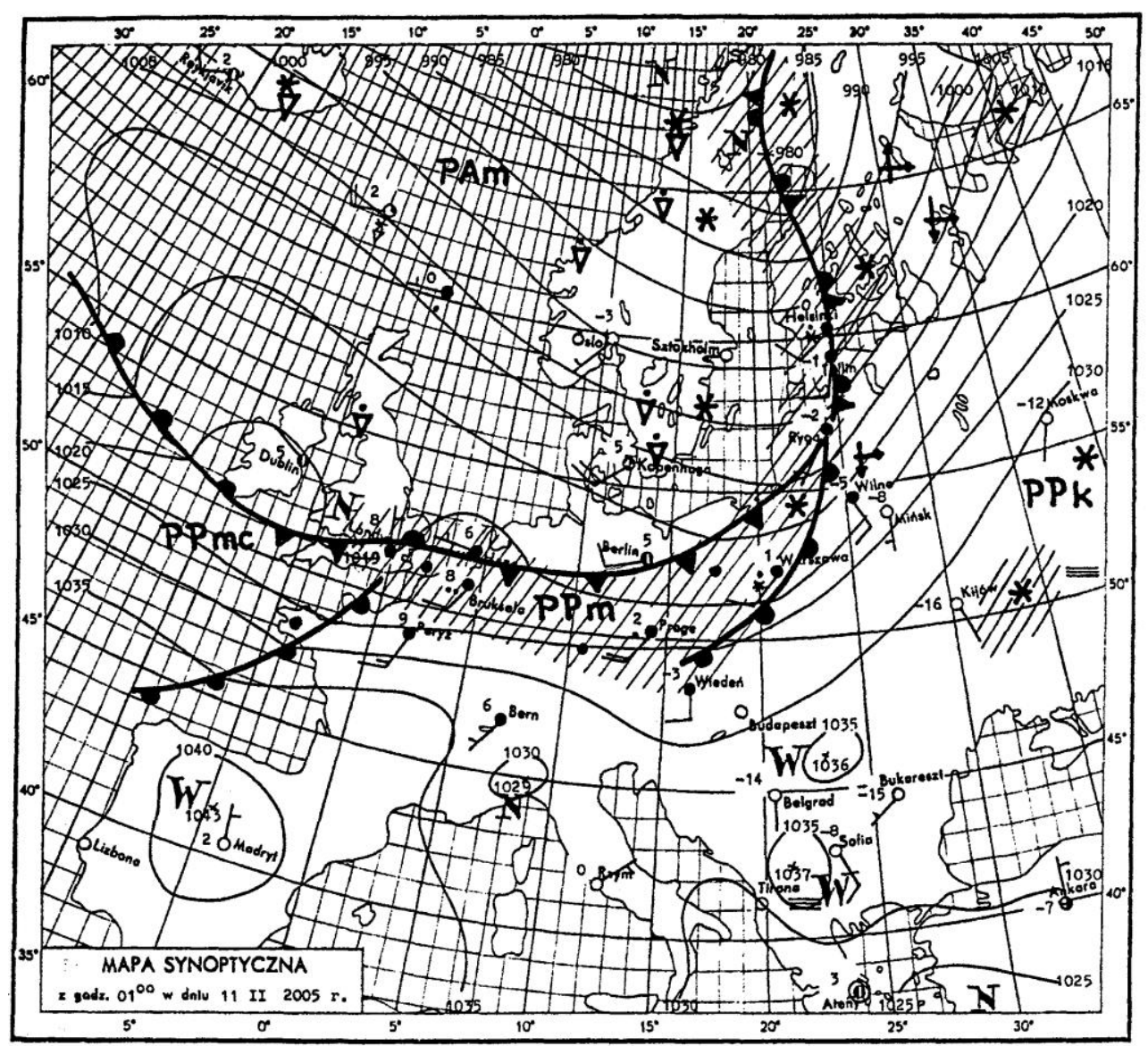

3d

Fig. 3. Synoptic situation during 04-11 February 2005 
Such strong high pressure atmospheric situation was the condition for inversion temperature development. The upper air soundings measurements made in Legionowo near Warsaw (Fig. 4) showed that from the station ground to a height of 430 meters the temperature raised up 13.8 degrees (from $-15.1^{\circ} \mathrm{C}$ to $-1.3^{\circ} \mathrm{C}$ ). Above the inversion layer started normal atmospheric temperature decrease with height. Such strong inversion caused drying the atmosphere and absence of clouds at all levels, which was the important factor for the thermal inversion development and air pollution concentration.
There are various classifications of circulation types occurring in Poland or in the Central Europe (NIEDŹWIEDŹ, 1981; USTRNul, 1997; HESS \& BREZOWSKY, 1952). Author used NiEDŹWIEDŹ (1981) classification, which takes into account the type of pressure system and the direction of air mass advection. This classification includes 21 types of circulation; 10 types describe anticyclones conditions, 10 cyclonic conditions and 1 type falls outside these categories. Table 1 presents the concrete macrocirculation types occured during the analyzed period.

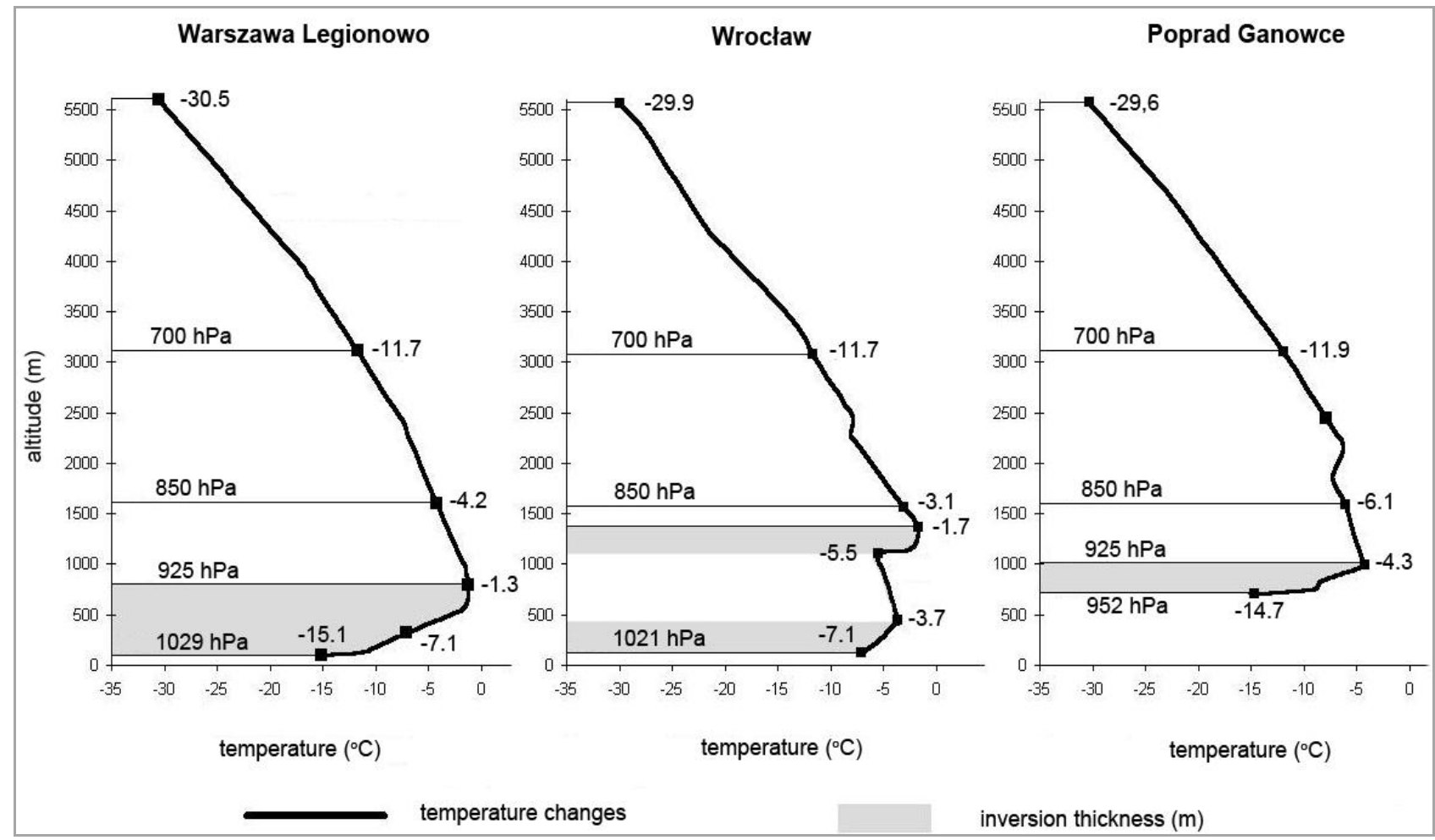

Fig. 4. High and thickness of inversion layer in 08.02.2005 00:00 UTC on three upper air soundings stations

Table 1. The macrocirculation types of Niedźwiedź (1981) in analyzed days

\begin{tabular}{|c|c|c|c|c|c|c|c|c|}
\hline Data & 04.02 .2005 & 05.02 .2005 & 06.02 .2005 & 07.02 .2005 & 08.02 .2005 & 09.02 .2005 & 10.02 .2005 & 11.02 .2005 \\
\hline $\begin{array}{l}\text { Circulation } \\
\text { type }\end{array}$ & Ea & SEa & SEa & SEa & Sa & Sa & SWa & Wa \\
\hline
\end{tabular}

\section{Air pollution vs. thermal inversion during 04.02 - 11.02.2005}

Temperature in cities situated in simple geographical conditions depends on the components of large-scale climate and characteristics of urbanization (PARK, 1987; UNGER ET AL., 2001; NIEDŹWIEDŹ, 2005). In urban areas, the heat exchange between the surface and the atmosphere is hard to estimate because of the significant diversification of surface types. Otherwise the thermal structure of the near-surface air can be easily observed and it could be an indicator of the surface characteristics.

Research conducted under the gradient measurements in Sosnowiec (BIL, 1999, 2000; CAPUTA, 2009) showed that it begin to expand from about 16 to 20 hours UTC, depending on the time of sunset in different seasons, and disappear between the hours of 4 and 9 UTC. Variation in the duration of each temperature inversion is very large: from several minutes to more than four days. The largest number of thermal inversions 
do not last longer than 1 hour. The second most common group are inversions of a duration of 6 to 12 hours, which are classical nocturnal inversion of radiation. The measured temperature differences can be treated as a vertical temperature gradient $(\Delta \mathrm{t})$ expressed in $\mathrm{K} / 100 \mathrm{~m}$.

Figure 6 presents the daily running of air temperatures measured in Sosnowiec at 2 and $100 \mathrm{~m}$ above the ground level. In the examined period, from 04.02-11.02.2005 the average temperatures equaled $-6.58^{\circ} \mathrm{C}$ at $2 \mathrm{~m}$ and $-5.92^{\circ} \mathrm{C}$ at $100 \mathrm{~m}$ above the ground level. The calculated gradient $(\Delta t)$ for $10 \mathrm{~min}$ equaled $0.6 \mathrm{~K} / 100 \mathrm{~m}$. Negative gradient occurred during the daytime in all analyzed days. Positive gradient occurred during the night-time and increased after sunset to its maximum values. Strictly after sunrise it rapidly decreased and change into negative gradient (Fig. 7). The strongest temperature inversion gradients $8.2 \mathrm{~K} / 100 \mathrm{~m}$. occurred at night of 8 February 2005 on $6: 10$ UTC and $7.5 \mathrm{~K} / 100 \mathrm{~m}$. at night of 9 February 2005 on 5:50 UTC (Fig. 7).

The values of the temperature gradient varied depending on the time of day and meteorological conditions. One of them is wind speed, which has considerable impact on the development and disappearance of the thermal inversion. The episode of 04-11 February 2005 is an example of the development and disappearance of temperature inversion during clear winter days with low wind speed (1-6 m/s). Low wind speed provides to the development of stable stratification (Fig. 4 and 8). The calm weather and the very high stable stratification resulted in air stagnation and the increase in aerosols and pollutants near the ground surface (Fig. 5 and 6-8). Additionally the absence of clouds brought on significant heat-loss of the surface during evenings and nights causing quick cooling in the near-surface layer of the atmosphere. The situation radically changed after midday of 10 February when the values of wind speed increased up to $16 \mathrm{~m} / \mathrm{s}$ (Fig. 8). Considering the latter group of the influencing factors, cloud coverage and radiation balance have the greatest impact (GEIGER ET AL., 1995).

According to CAPUTA ET. AL. (2009) in Sosnowiec dominate weak inversion, with an average intensity of 0.3-0.5 K. Under extreme conditions, it can go up to $13.5 \mathrm{~K}$, but its size can change quite quickly. It was observed that a gradient equal to or greater than $3 \mathrm{~K} / 100 \mathrm{~m}$ occurred in the presence of southwestern anticyclonic circulation (SWa), and southern anticyclonic circulation (Sa).

According to LESNIOK ET. AL. (2009) the radiation inversions plays a very important role in spread of air pollution. Generally days with anticyclonic circulations were characterized by considerable increases in concentrations of particulate matter $\mathrm{PM} 10$, sulphur dioxide $\mathrm{SO}_{2}$, nitrogen oxides ( $\mathrm{NO}$ and $\mathrm{NO}_{2}$ ). The distributions of selected concentrations of pollutants for each day differs signify, what is presented on Figs 6-8. We can divide it into two groups. First four days (04-07.02) showed slowly concentration of PM $10\left(50-150 \mu \mathrm{g} / \mathrm{m}^{3}\right), \mathrm{SO}_{2}(25-$ $\left.75 \mu \mathrm{g} / \mathrm{m}^{3}\right)$, $\mathrm{NO}\left(8-15 \mu \mathrm{g} / \mathrm{m}^{3}\right)$ and $\mathrm{NO}_{2}\left(15-40 \mu \mathrm{g} / \mathrm{m}^{3}\right)$. Second four days (8-11.02) showed significant increase of concentration values. The highest concentrations reached $414 \mu \mathrm{g} / \mathrm{m}^{3}$ (PM 10), $189 \mu \mathrm{g} / \mathrm{m}^{3},\left(\mathrm{SO}_{2}\right), 271 \mu \mathrm{g} / \mathrm{m}^{3}$ (NO) and $139 \mu \mathrm{g} / \mathrm{m}^{3}$ $\left(\mathrm{NO}_{2}\right)$ during days of the strongest vertical temperature gradient $(\Delta t)$. The first period was characterized by the circulations types SEa, Ea (south east and east anticyclonic). The second period was characterized by the circulations Sa, SWa.
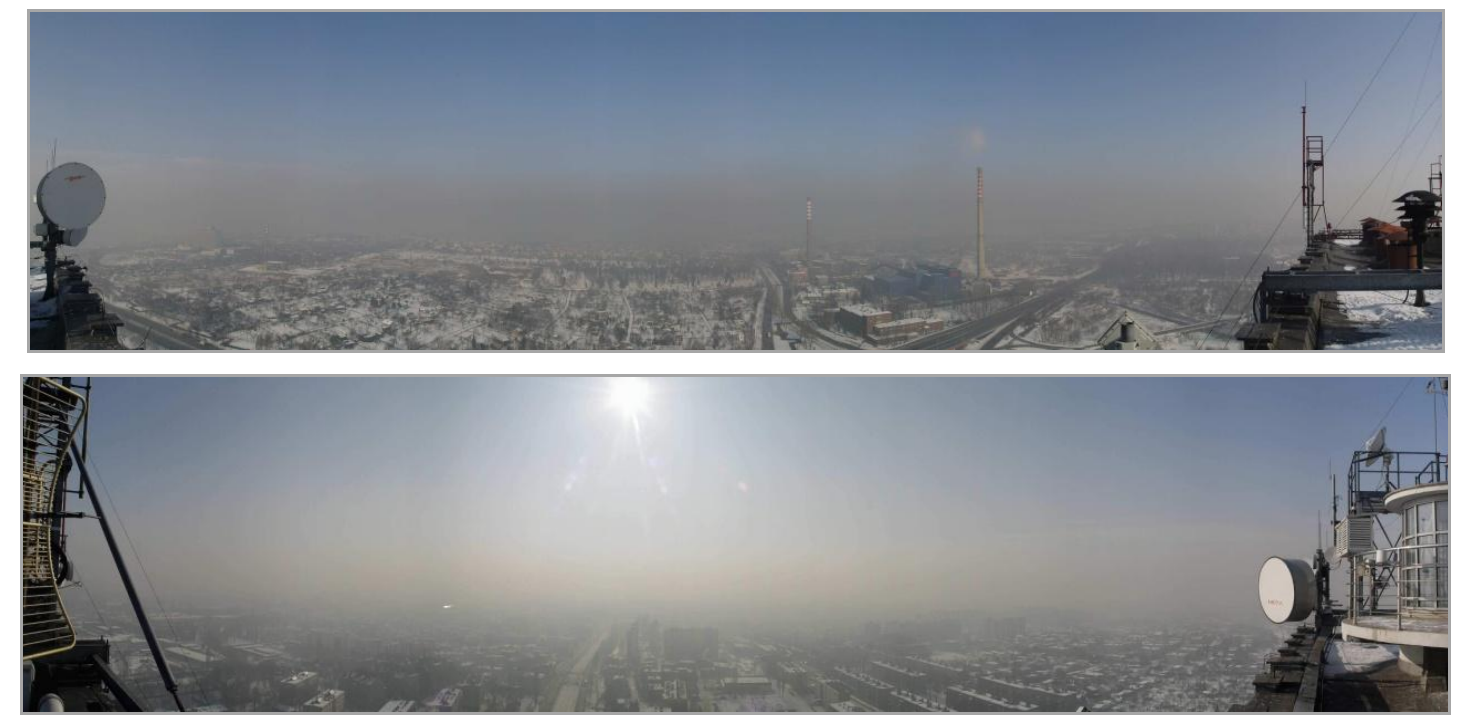

Fig. 5. The concentration of air pollutions during thermal inversion episode in Sosnowiec. Date: 8 February 2005. Time: 10:57 UTC. Location: roof of the Faculty of Earth Sciences. Direction: N (up) and S (down) (A. Widawski) 


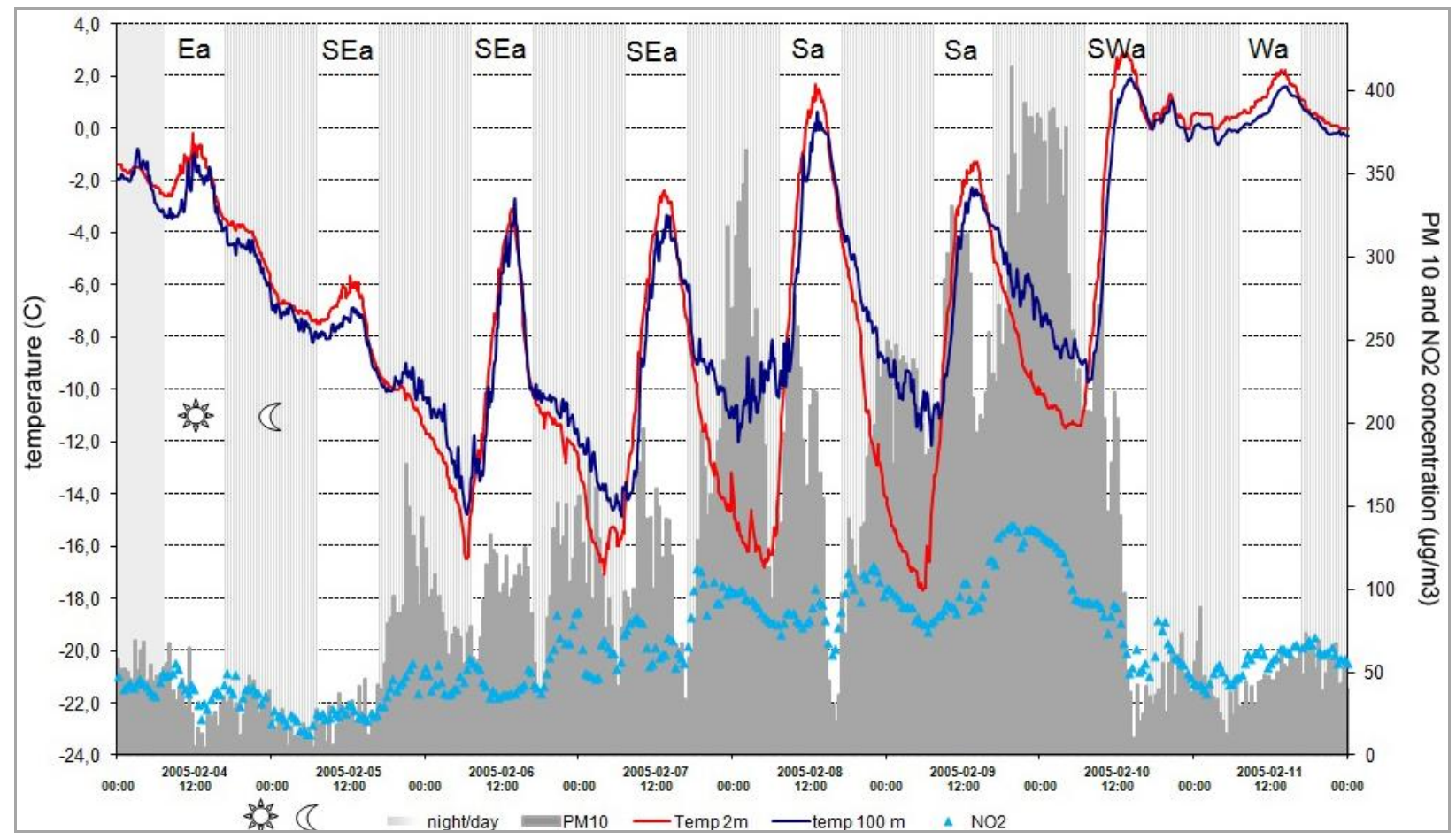

Fig. 6. Temperature running at $2 \mathrm{~m}$ a.s.l. (red), at $100 \mathrm{~m}$. a.s.l (dark blue) and PM 10, $\mathrm{NO}_{2}$ concentration in Sosnowiec during the thermal inversion episode

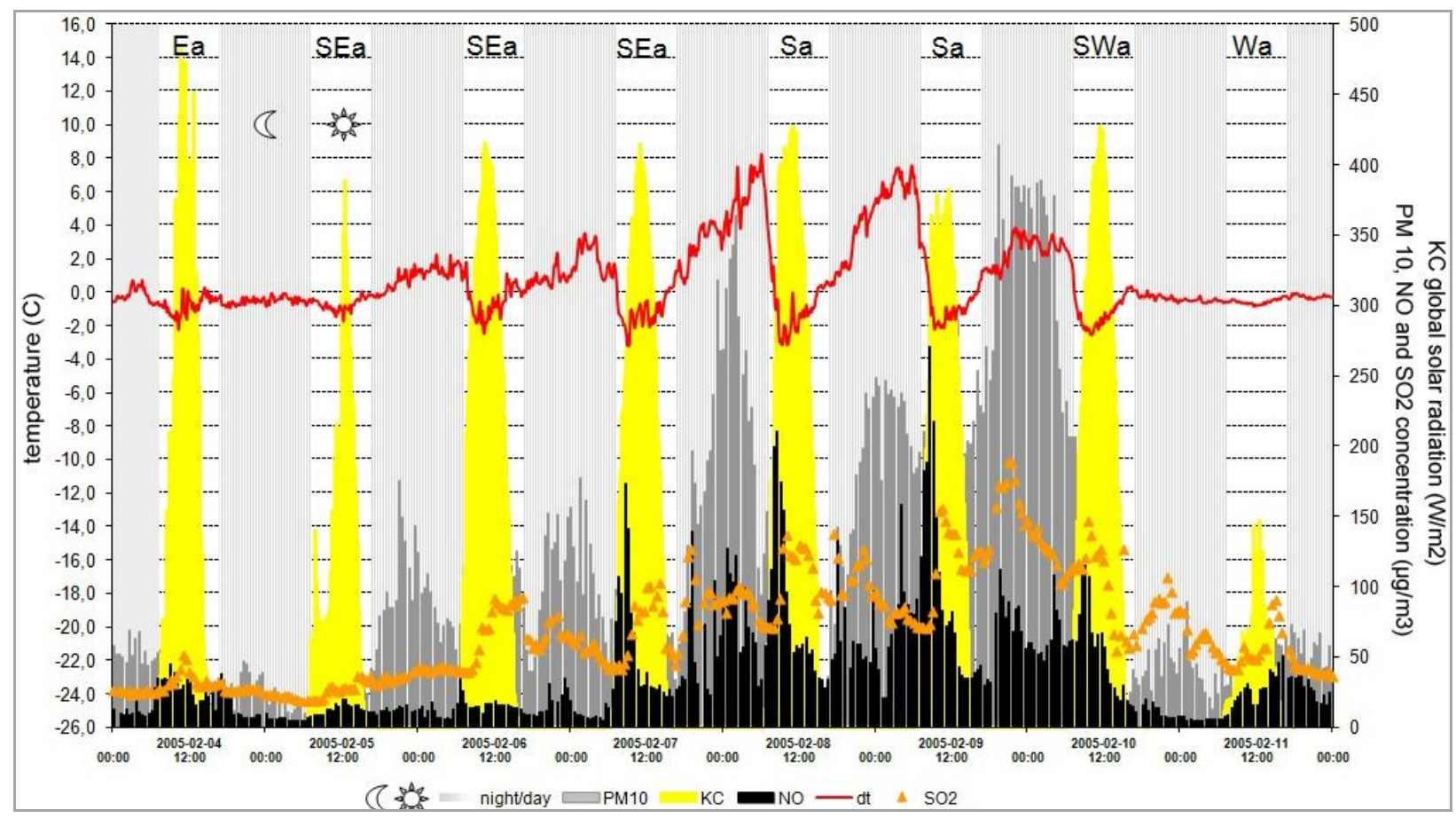

Fig. 7. Temperature differences $(\Delta \mathrm{t})$ between $2 \mathrm{~m}$ a.s.l. and $100 \mathrm{~m}$. a.s.l , PM 10, NO, $\mathrm{SO}_{2}$ concentration and global solar radiation in Sosnowiec during the thermal inversion episode

Such high values of measured pollutants in Sosnowiec are comparably with neighbor towns and regions. CEMBRZYŃSKA ET. AL. (2012) reported that the average concentrations of PM10 and PM2,5 in autumn-winter seasons in Sosnowiec city 20102011 were 2,1 to 2,7 times higher than limit of $50 \mu \mathrm{g} / \mathrm{m}^{3}$. BĄKOWSKA ET. AL. (2011) observed that every case when the allowed value was considerably exceeded (up to and above $100 \mu \mathrm{g} \cdot \mathrm{m}-3$ in Brno and upwards of $200 \mu \mathrm{g} \cdot \mathrm{m}-3$ in Sosnowiec and Cracow) was accompanied by a similar synoptic situation and weather conditions, i.e.an anticyclonic situation with an advection from the south or east. Additionally the highest PM10 dust concentrations occurred simultaneously at the three stations when Europe was under the influence of a vast and strong high pressure system, which suggests that they were caused by circulation factors operating at a scale greater than local. 


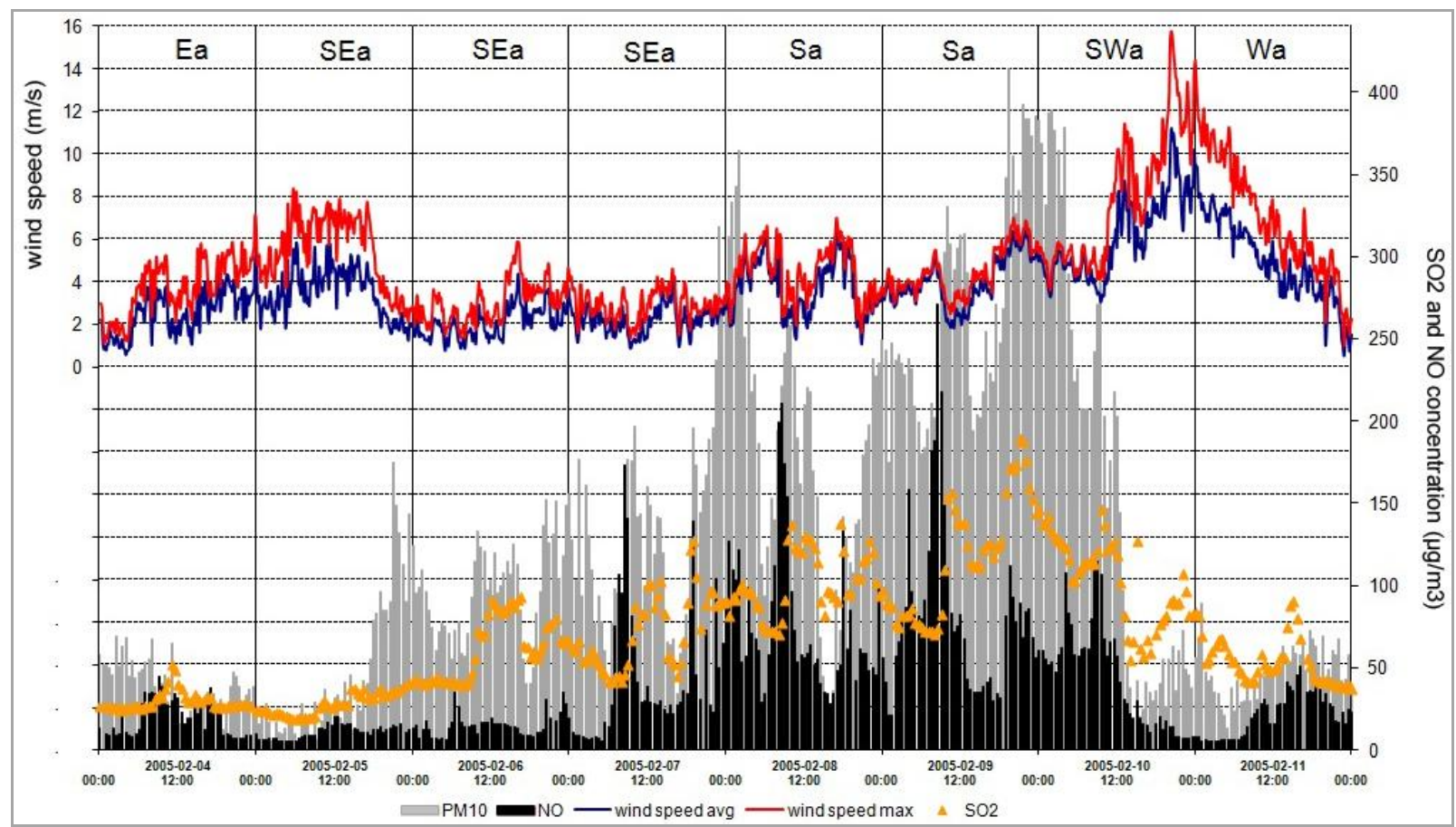

Fig. 8. Wind speed average (blue), wind speed maximum (red) and PM 10, NO, $\mathrm{SO}_{2}$ concentration in Sosnowiec during the thermal inversion episode

The analysis of particulate matter concentration in south Moravia in the context of circulation conditions was presented by KNOZOVA (2012). There was found, that the highest pollution occurred by anticyclonic types of weather, despite the fact they are scarcely then cyclonic types. The most PM10 concentrations and the most probability of overdraft daily standard of PM10 $50 \mu \mathrm{g} / \mathrm{m} 3$ occur by east anticyclonic situation (Ea), travelling central anticyclonic situation (Ap) and south-east anticyclonic situation (SEa).

The lowest values of pollutants concentrations during analyzed period were observed at the west antycyclonic circulations (Wa) at the end of analyzed period when the synoptic situation changed. For this day the values of all pollutants decreased rapidly in each of air pollution parameters.

Daily course of analyzed pollutants during thermal inversion episode provides to different conclusions. Generally it is strictly dependent on vertical profile gradient of temperature during the thermal inversion episode and times of sunrises and sunsets.

Particulate matter with a fraction size of up to $10 \mu \mathrm{m}$ (PM10) values had its maximum in the middle of the nights and days (i.e. $364 \mu \mathrm{g} / \mathrm{m}^{3}$ during night $7 / 8$ February) and its minimum at the sunrise and the sunset (i.e. $34 \mu \mathrm{g} / \mathrm{m}^{3}$ at sunset 7.02 and $94 \mu \mathrm{g} / \mathrm{m}^{3}$ at sunrise 8.02). See Figure 6 for more details.

Sulphur dioxide $\left(\mathrm{SO}_{2}\right)$ values before thermal inversion episode changed insignificant (4-5
February) but in the next few days $\mathrm{SO}_{2}$ values started to have its diurnal cycle. They increased during the days and nights into its maximum and then decreased at sunrise and sunset (Fig. 7).

Nitric oxide (NO) values, similarly to $\mathrm{SO}_{2}$, before thermal inversion episode changed insignificant (4-6 February) but in the next few days NO values started to have its diurnal cycle with its maximum values at the beginning of the day strictly after sunrise (i.e. $275 \mu \mathrm{g} / \mathrm{m}^{3}$ at sunrise 09 February). During the day the NO values decreased permanently (Fig. 7).

Nitrogen dioxide $\left(\mathrm{NO}_{2}\right)$ had its own daily course, similarly to NO, but without highest peaks after sunrise. $\mathrm{NO}_{2}$ diurnal amplitude was smaller than NO. The values of $\mathrm{NO}$ and $\mathrm{SO}_{2}$ had a tendency to scatter during the thermal inversion episode in comparison to days without it (Fig. 8).

\section{Conclusions}

During the analyzed episode of thermal inversion at 04-11 February 2005 anticyclonic types of circulation were presented. The most important for the strong development of the phenomena were SEa and Sa. Wa type finished analyzed period due to changes in synoptic situation in Europe.

Anticyclonic conditions have contributed to arise thermal inversion. The average temperatures of presented case study equaled $-6.58^{\circ} \mathrm{C}$ at $2 \mathrm{~m}$ and $-5.92^{\circ} \mathrm{C}$ at $100 \mathrm{~m}$ above the ground level. 
The calculated gradient $(\Delta t)$ for 10 min equaled $0.6 \mathrm{~K} / 100 \mathrm{~m}$. The strongest temperature inversion gradients $8.2 \mathrm{~K} / 100 \mathrm{~m}$. occurred at night 8 February 2005 on $6: 10$ UTC and 7,5 K/100 m. at night 9 February 2005 on 5:50 UTC. It was strong nocturnal inversion $(\Delta \mathrm{t} \geq 5 \mathrm{~K} / 100 \mathrm{~m})$ which occurred rather rare in winter.

The research on thermal structure of the inversion phenomenon with circulation conditions, confirmed the importance of these parameters affecting the air pollution levels. Generally analyzed days with anticyclonic circulations were characterized by considerable increases in concentrations of particulate matter PM10, sulphur dioxide $\mathrm{SO}_{2}$, nitrogen oxides ( $\mathrm{NO}$ and $\mathrm{NO}_{2}$ ) but the distributions of selected concentrations of pollutants for each day differs significantly. The highest mean concentrations reached $414 \mu \mathrm{g} / \mathrm{m}^{3}$ (PM 10), $189 \mu \mathrm{g} / \mathrm{m}^{3},\left(\mathrm{SO}_{2}\right), 271 \mu \mathrm{g} / \mathrm{m}^{3}$ (NO) and $139 \mu \mathrm{g} / \mathrm{m}^{3}\left(\mathrm{NO}_{2}\right)$ during days of the strongest vertical temperature gradient $(\Delta t)$. The highest concentrations of pollutants occurred during the anticycIonic conditions Sea, Sa and SWa.

Daily course of analyzed pollutants is strictly dependent on vertical profile gradient of temperature during the thermal inversion episode and times of sunrises and sunsets. It was noticed, that values of $\mathrm{PM} 10$ and $\mathrm{SO}_{2}$ changed significantly more than one time during the whole day. It have the tendency of scatter in comparison with days without inversion, too.

Comparison with other neighbor cities and regions shows that there are similarities in terms of weather conditions and circulation patterns that are responsible for the occurrence of high air pollution concentrations. As the result of the industry restructuring after the year 1989 the quantity of the emitted dust and gas pollutants in Katowice Region decreased, but in comparison with the other regions are still increased.

\section{References}

Bielec-Bąkowska Z., Knozova G., Leśniok M., Matuszko D., Piotrowicz K. 2011. High suspended dust concentrations in Brno, Sosnowiec and Krakow (the year 2009 as an example). Inst. Geogr. i Gospod. Przestrz. UJ w Krakowie, Prace Geogr., 126: 67-84.

Bil G. 1999. Prawdopodobieństwo występowania inwersji temperatury powietrza w Sosnowcu. [in:] Pełka-Gościniak J., Rzętała M. (eds.) Górnośląsko-ostrawski region przemysłowy. Wybrane problemy ochrony i kształtowania środowiska. Mat. symp. pol.-czes., Sosnowiec: 33-37.

Bil G. 2000. Inwersje temperatury w Sosnowcu. [in:] Jankowski A.T., Myga-Piątek U., Ostaficzuk S. (eds.) Środowisko przyrodnicze regionu górnośląskiego - stan poznania, zagrożenia i ochrona. Sosnowiec: 13-20.
Bil G., Caputa Z. and Kamiński A. 2003. Air temperature modification caused by thermal influence of a building. Acta Univ. Wratisl., Stud. Geogr., Wrocław, 75, 2542: 395-400.

Biuletyn regionalnego monitoringu środowiska (powietrze). Monografia systemu automatycznych pomiarów jakości powietrza w aglomeracji katowickiej. Wojewoda śląski, Katowice, 1999.

Caputa Z., Leśniok M., Niedźwiedź T., Puszczewicz Z., Widawski A. 2003. Research problems of urban and industrial areas climate in Department of Climatology. Faculty of Earth Sciences, Univ. of Silesia [in:] Kłysik K., Oke T., Fortuniak K., Grimmond S., Wibig J. (eds.) Proc. of V Int. Conf. on Urban Climate, Łódź: 47-50.

Caputa Z.A., Leśniok M.R., Niedźwiedź T., Bil-Knozova G. 2009. The influence of atmospheric circulation and cloudiness on the intensity of temperature inversions in Sosnowiec (Upper Silesia, Southern Poland). Int. J. Environ. Waste Manage., 4, 1/2:17-31.

Cembrzyńska J., Krakowiak E., Brewczyński P.Z. 2012. Zanieczyszczenie powietrza pyłem zawieszonym PM10 oraz PM2,5 w warunkach silnej antropopresji na przykładzie miasta Sosnowiec. Medycyna Środowiskowa, 15, 4: 31-38.

Geiger R., Aron R.H. and Todhunter P. 1995. The Climate Near the Ground. Vieweg, Braunschweig, Wiesbaden: I-S28.

Giridharan R., Lau S.S.Y., Ganesan S. 2005. Nocturnal heat island effected in urban residential developments of Hong Kong. Energy and Buildings, 37: 964-971.

Haeger-Eugensson M., Holmer B. 1999. Advection caused by the urban heat island circulation as a regulating factor on the nocturnal urban heat island, Int. J. of Climatol., 19: 975-988.

Hess P. and Brezowsky H. 1952. Katalog der Grosswetterlagen Europas. Ber. Dl. Wetterdienst in USZone, 33: 39.

Hławiczka S., Dyduch B., Fudała J. 2003. Long-term changes of particulate emission in the industrial region of Upper Silesia (Poland) and their effect on the acidity of rainwater. Water, Air Soil Poll., 142: 151-163.

Kłysik K., Fortuniak K. 1999. Temporal and spatial characteristics of the urban heat island of Łódź, Poland. Atmos. Environ., 33: 3885-3895.

Knozova G. 2012. Zanieczyszczenie pyłem zawieszonym na Morawach południowych przy różnych typach cyrkulacji [in:] Bielec-Bąkowska Z., Łupikasza E., Widawski A. (eds.) Rola cyrkulacji atmosfery w kształtowaniu klimatu. Kat. Klimat., Wydz. Nauk o Ziemi, Uniw. Śl., Sosnowiec: 287-297.

Leśniok M. 1996. Zanieczyszczenie wód opadowych w obrębie Wyżyny Ślq̨sko-Krakowskiej. Rozpr. dokt., Wyd. Uniw. Śl., Katowice.

Leśniok M.R., Caputa Z.A. 2009. The role of atmospheric circulation in air pollution distribution in Katowice Region (Southern Poland). Int. J. Environ. Waste Manage., 4, 1/2: 62-74.

Leśniok M., Małarzewski Ł., Niedźwiedź T. 2010. Classification of circulation types for Southern Poland with an application to air pollution concentration in Upper Silesia. Phys. Chem. of the Earth, 35: 516-522.

Leśniok M. 2011. Changeability of Air Pollution in Katowice Region (Central Europe, Southern Poland), Advanced Air Pollution, Dr. Farhad Nejadkoorki (ed.), ISBN: 978-953307-511-2, InTech, Available from: ttp://www.intechopen. com/books/advanced-air-pollution/changeability-of-airpollution-in-katowiceregion-central-europe-southern-poland

Niedźwiedź T. 1981. Sytuacje synoptyczne I ich wpływ na zróżnicowanie przestrzenne wybranych elementów klimatu $w$ dorzeczu górnej Wisły. Rozpr. Habil., Uniw. Jagiell., Kraków: 58. 
Niedźwiedź T. 2005. The role of cities in climate modification selected issues. Global Change, 12: 23-33.

Niedźwiedź T. 2006. Katalog sytuacji synoptycznych i wskaźników cyrkulacji w dorzeczu górnej Wisły (18732006). Dostępny w internecie - Kat. Klimat,. Uniw. Śl., Sosnowiec.

Niedźwiedź T., Olecki Z. 1994. Wpływ sytuacji synoptycznych na zanieczyszczenia powietrza w Krakowie. [in:] Przemiany środowiska geograficznego Krakowa i ich skutki. Zesz. Nauk. UJ, Prace Geogr., 96: 55-68.

Niedźwiedź T., Ustrnul Z. 1989. Wpływ sytuacji synoptycznych na występowanie nad Górnośląskim Okręgiem Przemysłowym typów pogody sprzyjających koncentracji lub rozpraszaniu zanieczyszczeń powietrza. Wiad. IMGW, 12, 1-2: 31-39.

Oke T.R. 1999. Urban environments, [in:] Bailey W.G., Oke TR., Rouse W.R. (eds) The surface climates of Canada. McGill-Queen Univ. Press: 303-327.

Ośródka L. 1991. Zróżnicowanie klimatu GOP na przykładzie warunków termicznych. Rozpr. dokt., Kraków, Katowice.

Ośródka L., Ośródka K., Święch-Skiba J. 1999. Smog zimowy w Górnośląskim Okręgu Przemysłowym jako jeden ze skutków antropogenicznych zmian klimatu lokalnego. Acta Univ. Lodz., Folia Geogr. Physica, 3: 361-369.

Park H. 1987. Variations in the urban head island intensity affected by geographical environments. Environ. Res. Center Papers, Univ. of Tsukuba, 11: 1-79.

Paszyński J. 1997. Introduction to the problems on local climate and man. [in:] Yoshino M., Domros M., Dougućdroit A, Paszyński J., Nkemdirim LC. (eds). Climates and Societies - A Climatological Perspective. Kluver Acad. Publ., Dordrecht, Boston, London: 327-331.
Rogula-Kozłowska W., Kozielska B., Klejnowski K., Szopa S. 2013. Hazardous compounds in urban PM in the central part of Upper Silesia (Poland) in winter. Arch. Environ. Prot., 39, 1: 53 - 65, Doi: 10.2478/Aep-2013-0002.

Szymanowski M. 2005. Interactions between thermal advection in frontal zones and urban heat island of Wrocław, Poland. Theor. Appl. Climatol., 82: 207-224.

Twardosz R., Niedźwiedź T. 2001. Influence of synoptic situation on the precipitation in Kraków (Poland). Int. J. Climatol., 21, 4: 467-481.

Unger J., Sumeghy Z., Zoboki J. 2001. Temperature crosssection features in an urban area. Atmos. Res., 58: 117-127.

Ustrnul Z. 1997. Zmienność cyrkulacji atmosfery na półkuli północnej w XX wieku. Mat. Bad., Ser. Meteorol., Inst. of Meteorol. and Water Manage., Warszawa, 27.

Wiatrak W. 1989. Antropogeniczny bilans cieplny w województwie katowickim. Wiad. IMGW, 12 (33), 1-2: 71-79.

Wilmers F. 1997. Interactions of man and climate in the urban world - the influence of urbanization on the local climate and the influence of urban climate on man [in:] Yoshino M., Domros M., Dougućdroit A, Paszyński J., Nkemdirim LC, (eds). Climates and Societies - A Climatological Perspective. Kluver Acad. Publ., Dordrecht, Boston, London: 333-359.

Wyoming Weather Web at http://weather.uwyo.edu/ upperair/sounding.html (25.04.2015) 